\title{
STABILIZATION OF PAVEMENT SUBGRADE BY USING FLY ASH REINFORCED WITH GEOTEXTILE
}

\author{
S. Siva Gowri Prasad ${ }^{1}$, Suresh Kumar .ch ${ }^{2}$, Ramesh Surisetty \\ ${ }^{1}$ Assistant professor, Department of civil Engg, GMRIT, Rajam, A.P India \\ ${ }^{2}$ Post graduate student, Department of civil Engg, GMRIT, Rajam, A.P India \\ ${ }^{3}$ Post graduate student, Department of civil Engg, GMRIT, Rajam, A.P India
}

\begin{abstract}
The performance of a pavement is very responsive to the characteristics of the soil subgrade, which provides base for the whole pavement structure. For that reason of utmost significance the performance of pavements is enhanced by adopting proper design and construction schemes. Million tons of fly ash produced from various thermal power plants is low unit weight, non-plastic, very fine and disposed in slurry form into ponds covering huge area. The ash acquired from ponds gets directly air-borne and thus constitutes a serious pollution threat to the society. These materials have a low load carrying capacity, degraded settlement distinctiveness and their utilization in civil engineering works is a tough assignment. On the other hand the performance of these materials can be improved by using soil reinforcement procedure. It can be used as a pavement sub grade with the help of Geotextile sheets as reinforcement. In this study, samples of fly ash compacted to its maximum dry density at the finest moisture content is organized without and with Geotextile layers in the CBR mould. Geotextile sheets equal to the plan dimensions of CBR mould is placed in distinct preparations of $1^{\text {st }}, 2^{\text {nd }}, 3^{\text {rd }}$ and $4^{\text {th }}$ layers at different locations (i.e. at different embedment ratio, $z / d$ ) in the CBR mould. Subsequent to each arrangement of Geotextile, the CBR (California Bearing Ratio) values are evaluated in the laboratory and compared with the results of CBR values earlier than including geotextiles.
\end{abstract}

Keywords: Soil, fly ash, Geotextile, Stabilization, CBR.

\section{INTRODUCTION}

Pavements either bound or unbound are exposed to repeated, high and focused loads. These can cause precipitate aging and failure of the road construction. Roads \& Pavement reinforcement increases the life of service of the roads and highways by decreasing fatigue, reflective, thermal and settlement cracking. Roads \& Pavement reinforcement relieves and redistributes stress concentrations in the pavement.

Subgrade can be defined as a compacted layer, generally of naturally happening local soil, assumed to be $300 \mathrm{~mm}$ in thickness, just below the pavement crust, providing appropriate foundation for the pavement. The subgrade in embankment is compacted in two layers, generally to a higher standard than the lower part of the embankment. The subgrade, whether in cutting or in embankment, should be well compacted to utilize its full strength and to economize on the overall pavement thick

Ayyappan et. al (2010) [9] have been investigated separately either on fly ash / lime stabilization of soil or fiber reinforced soil. Sharma (2012) [10] investigated on the behaviour of expansive soil modified with blend of soil, fly ash and Recron $3 \mathrm{~S}$ fibre of $12 \mathrm{~mm}$ length. Raji et. al (2011) [1] investigated on the application of fly ash and/or coir geotextile by accomplished various laboratory tests, including compaction and California Bearing Ratio (CBR) tests. A field simulation was carried out on selected subgrade systems using a Wheel Tracking, Karthik et. al
(2014) [7] observed the effect of Fly ash derived from burning of sub-bituminous coal at electric power plants in stabilization of soft fine-grained red soils. H. P. Singh et. Al (2013) [6] studied that soil can be reinforced with Jute fiber and CBR tests were carried out with and without reinforcementness. The current MORTH Specifications require that the subgrade should be compacted to $100 \%$ MDD attained by the Modified Proctor Test (IS 2720-Part 7 ). For both major roads and rural roads the material used for subgrade construction should have a dry unit weight of not less than $16.5 \mathrm{kN} / \mathrm{m}^{3}$.

\section{MATERIALS USED}

\subsection{Soil}

The soil sample used for this study is collected near LIC Building, Srikakulam road, Rajam, at a depth of $1.0 \mathrm{~m}$ beneath the ground surface. The soil is primarily allowed to dry for 2 days and the dried soil is thoroughly grinded. The grinded soil is allowed to pass through $4.75 \mathrm{~mm}$ IS sieve and the passed soil is used for the current study. Soil passing through 425 microns sieve is used for influential liquid limit and plastic limit. The soil contains $65 \%$ of fines. The Index and engineering properties of the soil were present in table: 1

\subsection{Flyash}

Fly ash is an essential industrial by-product that comes from the burning of coal, used for the production of electrical energy. In our country, only a small percentage of this is 
used for the construction of technical projects, while the rest is dumped (stockpiled), which causes serious problems to the accessible environment. It has been found that stabilization with fly ash, improves the engineering and mechanical characteristics of soil, so it is a viable option to use fly ash as a modifier. Stabilization of soils and pavement bases with coal fly ash is gaining rising popularity among pavement engineers in the recent past. The fly ash used in this study was collected from the NATIONAL THERMAL POWER CORPORATION (NTPC), Vishakhapatnam. The grade of fly ash used in the experimental work is " $F$ " grade. The chemical composition of fly ash shown in table: 2

\subsection{Geo Textile}

Geotextile can be simply defined as "a textile material used in a soil (geo) environment" and consist of woven and nonwoven polymeric materials and natural materials, such as jute, constructed using textile processes.

Polypropylene: The polymerization of propylene monomers in the presence of specific catalyst produces the crystalline thermoplastic polypropylene. It is very liable to oxidation and additives are necessary to protect against ageing. Other additives are also used to improve thermal stabilization, UV resistance and underwater resistance. The Geotextile used in this study is poly propylene non woven Geotextile obtained from Ayyappa Geosynthetics installers, lankelapalem near Vishakhapatnam. The different properties of geotextile are show in table: 3

Table: 1 Geotechnical properties of the unmodified soil

\begin{tabular}{|l|l|l|}
\hline Sl. No & Property & Value \\
\hline 1 & Gravel & $1.4 \%$ \\
\hline 2 & Sand & $33.5 \%$ \\
\hline 3 & Fines (silt + clay) & $65.1 \%$ \\
\hline 3 & Bulk density & $2.1 \mathrm{~g} / \mathrm{cc}$ \\
\hline 4 & Specific gravity & 2.64 \\
\hline 5 & Liquid limit & $36.60 \%$ \\
\hline 6 & Plastic limit & $22.14 \%$ \\
\hline 7 & Plasticity Index & $14.46 \%$ \\
\hline 8 & Optimum moisture content & $17.4 \%$ \\
\hline 9 & Maximum Dry Density & $1.75 \mathrm{~g} / \mathrm{cc}$ \\
\hline 10 & I.S classification & Sandy Silt \\
\hline
\end{tabular}

Table: $\mathbf{2}$ Chemical composition of fly ash

\begin{tabular}{|l|l|l|}
\hline S1. NO. & Chemical component & $\begin{array}{l}\text { Chemical content by } \\
\% \text { wt }\end{array}$ \\
\hline 1 & $\mathrm{SiO}_{2}$ & 59 \\
\hline 2 & $\mathrm{AlO}_{3}$ & 16.40 \\
\hline
\end{tabular}

\begin{tabular}{|l|l|l|}
\hline 3 & $\mathrm{Fe} \mathrm{O}_{3}$ & 6.30 \\
\hline 4 & $\mathrm{CaO}$ & 5.93 \\
\hline 5 & $\mathrm{MgO}$ & 2.25 \\
\hline 6 & $\mathrm{SO}_{3}$ & 1.00 \\
\hline 7 & $\mathrm{LOI}$ & 4.62 \\
\hline
\end{tabular}

Table: 3 Properties of Geotextile

\begin{tabular}{|c|c|c|}
\hline PROPERTIES & UNITS & FPEG-2 \\
\hline MASS (ASTM -D 5311) & $\mathrm{Gms} / \mathrm{M}^{2}$ & 200 \\
\hline $\begin{array}{l}\text { TENSILE STRENGTH (ASTM - D } \\
4595)\end{array}$ & $\mathrm{KN} / \mathrm{m}$ & 6 \\
\hline $\begin{array}{lll}\text { GRAB } & \text { TENSILE } & \text { STRENGTH } \\
\text { (ASTM-D } & \text { 4632) } & \end{array}$ & $\mathrm{N}$ & 600 \\
\hline 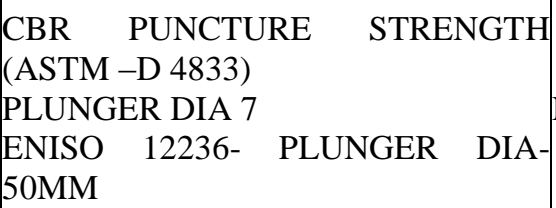 & $\mathrm{N}$ & $\mid \begin{array}{l}600 \\
1200\end{array}$ \\
\hline $\begin{array}{l}\text { TRAPESOIDAL TEAR STRENGTH } \\
\text { ASTM D } 4632\end{array}$ & $\mathrm{~N}$ & 175 \\
\hline A.O.S. & $\mathrm{m}$ & $<75$ \\
\hline ROLL WIDTH & MTR & 4 \\
\hline
\end{tabular}

\section{METHODOLOGY}

Compaction tests were carried out for different flyash contents to determine the maximum dry density (MDD) and optimum moisture content (OMC). This flyash content is used for the further CBR tests. CBR tests were conducted by following the procedure given in IS code.

The Geotextile was applied in different layers in the specimen as mentioned below.

$1.1^{\text {st }}, 2^{\text {nd }}, 3^{\text {rd }}$ and $4^{\text {th }}$ layers in each

2. $1^{\text {st }}$ and $3^{\text {rd }}$ layers, $2^{\text {nd }}$ and $4^{\text {th }}$ layers and at all the layers. 
The positions of Geotextile placed is illustrated in figure: 1

Loading

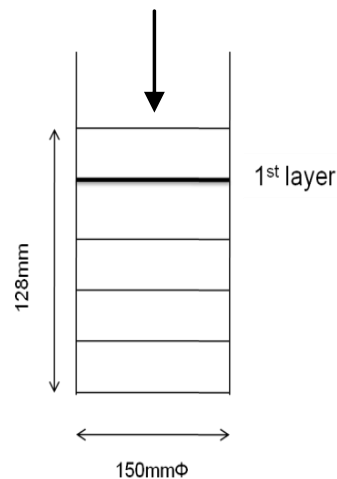

1 (a)

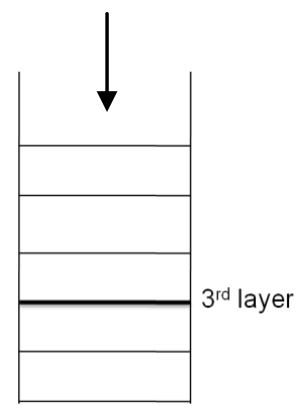

$1(\mathrm{c})$

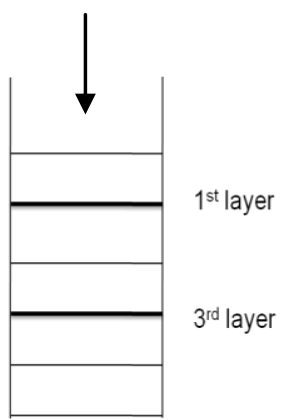

$1(\mathrm{e})$

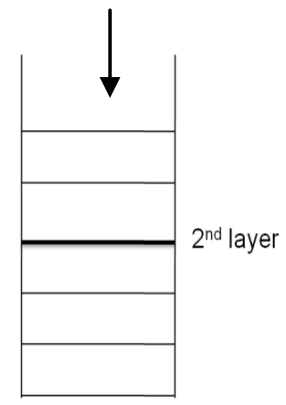

$1(b)$

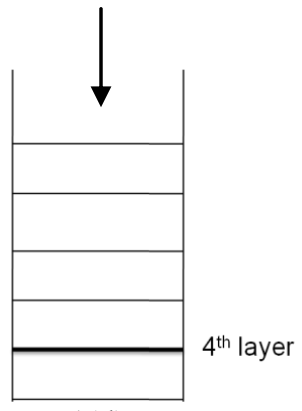

$1(\mathrm{~d})$
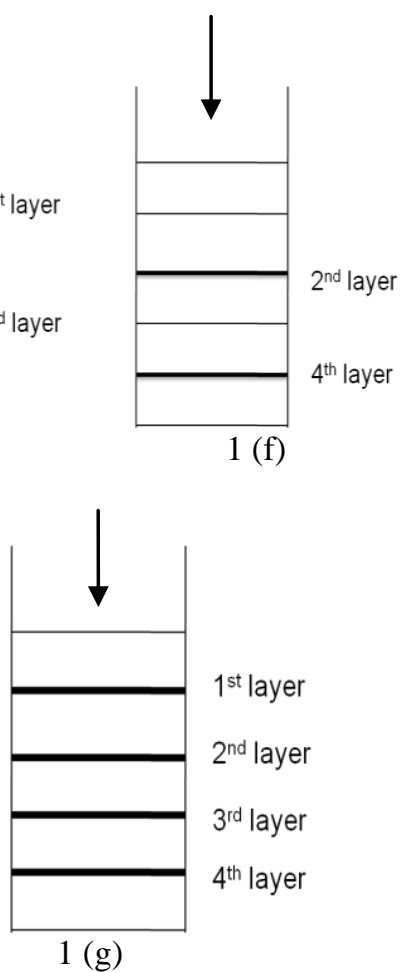

Fig 1: Geotextile layers

Summary of test results of soil modified with flyash reinforced geotextiles are given below. Compaction test results are presented in table: 4 and CBR results are presented in table: 5
Table 4: Compaction test results by varying the fly ash

\begin{tabular}{|l|l|l|}
\hline S. No & OMC $(\%)$ & MDD (g/cc) \\
\hline Unmodified Soil & 17.40 & 1.75 \\
\hline Soil+6\%fly ash & 20.24 & 1.60 \\
\hline Soil+8\%fly ash & 18.20 & 1.73 \\
\hline Soil+10\%fly ash & 17.58 & 1.7 \\
\hline
\end{tabular}

Table 5: Test results for Unsoaked and Soaked CBR

\begin{tabular}{|l|l|l|}
\hline \multirow{2}{*}{ S.NO } & \multicolumn{2}{|l|}{ CBR Value } \\
\cline { 2 - 3 } & Unsoaked & Soaked \\
\hline Unmodified & 2.92 & 1.55 \\
\hline Modified & 3.01 & 1.82 \\
\hline 1st layer & 3.83 & 2.38 \\
\hline 2nd layer & 3.74 & 2.19 \\
\hline 3rd layer & 3.46 & 2.10 \\
\hline 4th layer & 3.10 & 2.00 \\
\hline 1st and 3rd layers & 3.92 & 3.00 \\
\hline 2nd and 4th layers & 5.01 & 3.64 \\
\hline 1st ,2nd 3rd and 4th layers & 5.47 & 4.00 \\
\hline
\end{tabular}

\section{ANALYSIS AND DISCUSSION OF TEST}

\section{RESULTS}

Test data signified through figures to analyse the influence of fly ash on soil with respect to OMC, MDD and the effect of geotextile on the CBR values.

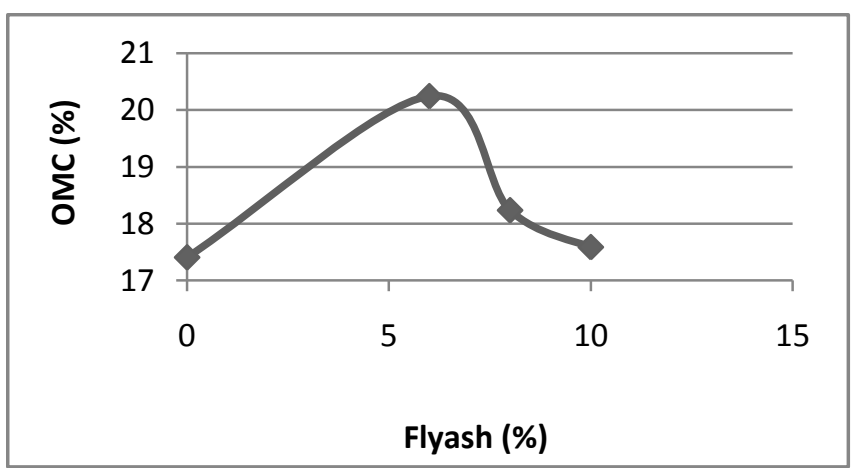

Fig 2: Compaction curve for OMC and Percentage flyash

The OMC value for natural soil is $17.4 \%$. By increasing the Fly ash content, the OMC value increases to $20.24 \%$ at $6 \%$ flyash and decreased by further increasing the flyash content. This may be due to the mixture requires more water to coat the particles each other. 


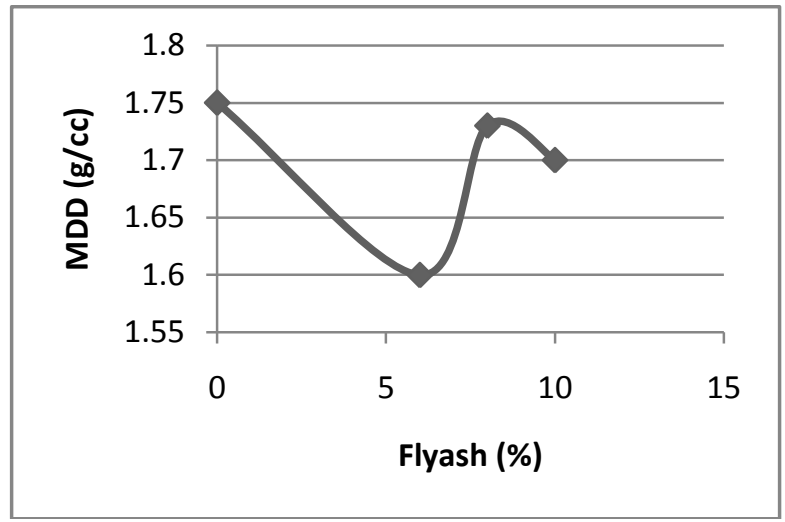

Fig 3: Compaction curve for MDD and Percentage of flyash

The MDD value for natural soil is $1.75 \mathrm{~g} / \mathrm{cc}$. By increasing the fly ash from $6 \%$ to $10 \%$, the dry density value is reduced compared to the natural soil. This may be due to low specific gravity of the flyash compared to the soil. Whereas with-in these three values the maximum dry density achieved is $1.73 \mathrm{~g} / \mathrm{cc}$ at $8 \%$ replacement. This flyash content is used for the further CBR tests.

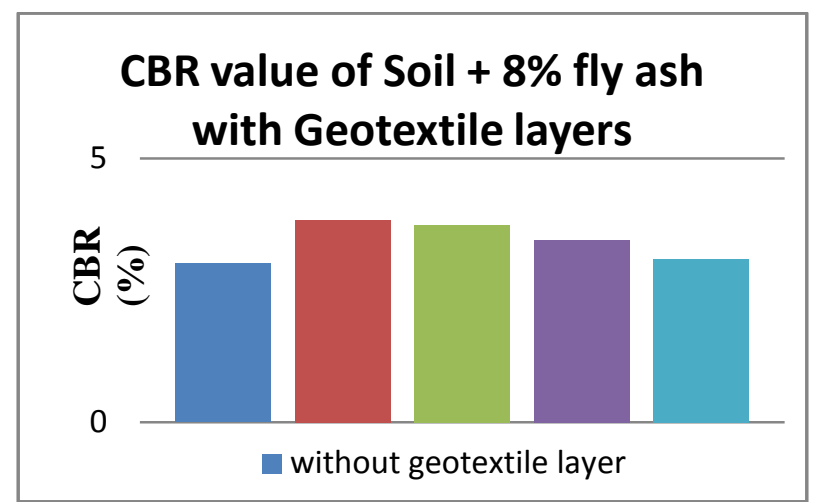

Fig 4: Variation of Unsoaked CBR values with and without Geotextile layer in each

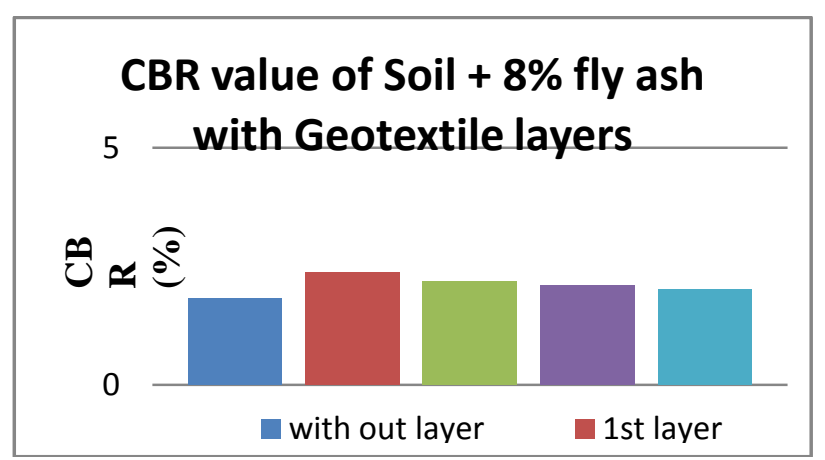

Fig 5: Variation of Soaked CBR without and with Geotextile layer in each

The CBR value for natural soil is $1.55 \%$. By the addition of fly ash, the CBR value increased to $1.82 \%$ which is an increment of $17.42 \%$. The CBR value obtained is $2.38 \%$ when the geotextile is placed at $1^{\text {st }}$ layer is maximum when compared to other three individual layers. The percentage CBR is $53.54 \%$ compared to that of natural soil.

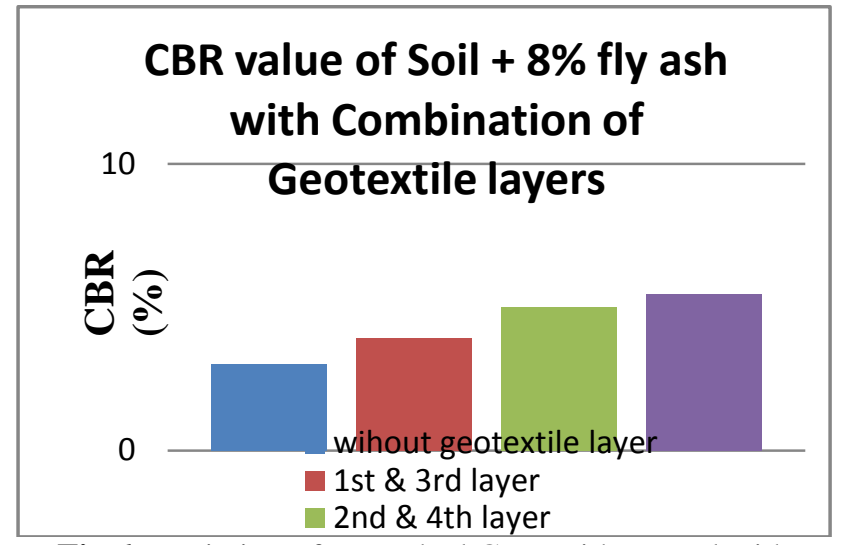

Fig 6: Variation of Unsoaked CBR without and with combinations of Geotextile layer

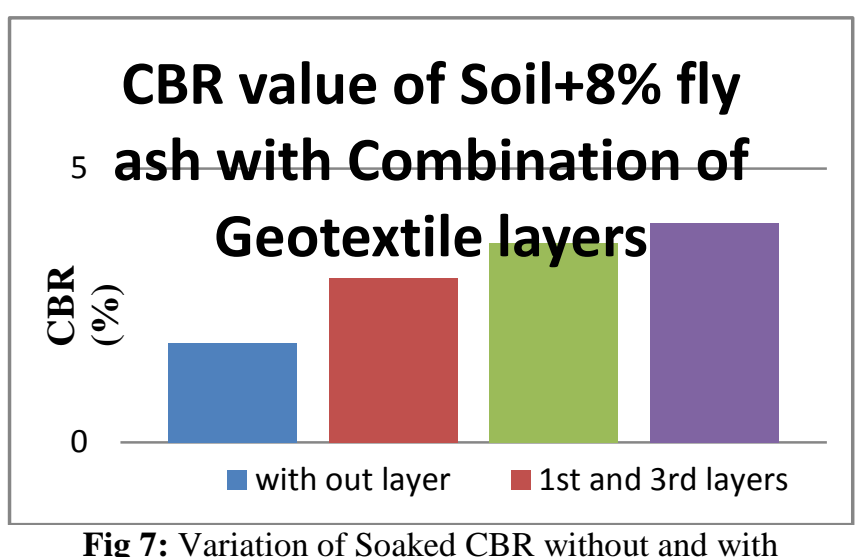

Fig 7: Variation of Soaked CBR without and with combinations of Geotextile layer

The CBR value of $3.0 \%$ is obtained when the geotextile is placed at $1^{\text {st }}$ and $3^{\text {rd }}$ layers. Here the percentage increase in CBR value is $93.54 \%$ compared to that of natural soil. The CBR value of $3.64 \%$ is obtained when the geotextile is placed at $2^{\text {nd }}$ and $4^{\text {th }}$ layers. Here the percentage increase in CBR value is $134.83 \%$ compared to that of natural soil which is more than the results obtained when the geotextile is placed at $1^{\text {st }}$ and $3^{\text {rd }}$ layers.

The CBR value of $4.0 \%$ is obtained when the geotextile is placed at all four layers which is an increment of $158.0 \%$ compared to the unmodified soil.

\section{CONCLUSIONS}

Based on the tests conducted and discussion in earlier chapters following conclusions have been made.

- $\quad$ By addition of fly ash, the CBR value is increased by $27 \%$ when compared to unmodified soil.

- $\quad$ The CBR value is increased by $28.4 \%$ where the geotextile is placed at $1^{\text {st }}$ layer when compared to other three layers.

- The CBR value is increased by $64 \%$ where the geotextile is placed at $2^{\text {nd }}$ and $4^{\text {th }}$ layers when compared to $1^{\text {st }}$ and $3^{\text {rd }}$ layers.

- $\quad$ The CBR value is increased by $158.0 \%$ by placing the geotextile at all four layers compared to the unmodified soil. 
- $\quad$ By placing the geotextile in between the subgrade layers, the properties of the soil can be increased and ultimately reduces the subgrade layer thickness, showing cost- effective pavement.

\section{REFERENCES}

[1] A. K. Raji, Assistant Professor Proceedings of Indian Geotechnical Conference December 15-17, 2011, Kochi (Paper No.J-258) Study Of Rut Behaviour Of Coir Reinforced Black Cotton Soil Using Wheel Tracking Apparatus.

[2] Bairwa Ramlakhan International Journal of Emerging Technology and Advanced Engineering in the year November 2013 Effect of lime and fly ash on Engineering Properties of Black Cotton soil.

[3] Dr. Mehboob Anwer Khan- Geotechnical Engineering Section ,Department Of Civil Engineering, Aligarh Muslim, University, Aligarh-A Cbr Based Study Evaluating Sub Grade Strength Of Flexible Pavements Having Soil Flyash Interfaces.

[4] Dave guram, mark marienfeld, and curtis hayes, Evaluation Of Nonwoven Geotextile Versus LimeTreated Subgrade In Atoka County, Klahoma.

[5] H.P.Singh,M.Bagra,International Journal Of Innovative Research In Science,Engineering And Technology (Iso 3297:2007 Certified Organization) Vol. 2, Issue 8, August 2013 Improvement In Cbr Value Of Soil Reinforced With Jute Fiber.

[6] H. P. Singh And Omo Yachang, Use Of Fly Ash Reinforced With Jute Geotextile As A Pavement Subgrade, Department Of Civil Engineering, Nerist and Itanagar 791109.

[7] Prof.S.Ayyappan, Ms.K.Hemalatha and Prof.M.Sundaram ,International Journal of Invironmental Science and Development, Vol. 1, No. 2, June 2010nvestigation of Engineering Behavior of Soil,Polypropylene Fibers and Fly Ash Mixtures for Road Construction.

[8] Prof. R.K Sharma , (ICEES'2012) march 17-18, 2012 Bangkok, Subgrade Characteristics of Locally availablesoil Mixed With Fly Ash and randomlydistributed Fibers.

[9] Satyendra Mittal, P. K. Choudhury, T. Sanyal and B. Chandrashekhar application of jute geotextile in improving permeability of sub soil.

[10] S. Chakrabarti, G. Bhandari influence of geojute reinforcement on thickness reduction of flexible pavement - a model study.

[11] Venkata Koteswara Rao Pasupuleti, Satish Kumar Kolluru- Effect Of Fiber On Fly-Ash Tabilized Sub Grade Layer Thickness-International Journal Of Engineering And Technology (Ijet),Department Of Civil EngineeringVignan University, Vadlamudi, Guntur, Andhra Pradesh522213.

[12] Karthik.S, Ashok kumar.E, Gowtham.P, Elango.G, Soil Stabilization by Using Fly Ash, in the year Jan. 2014.

[13] Khan Tabassum,Saxena Anil Kumar , Associate Professor,Arorat.R. Osr Journal Of Mechanical And Civil Engineering (Iosr-Jmce) E-Issn: 2278-1684,P-
Issn: 2320-334x, Volume 9, Issue 5 (Nov. - Dec. 2013), Pp 15-19 -Performance Evaluation Of Locally Available Soil Mixed With Fly Ash And Randomly Distributed Nylon Fibers. 